Check for updates

Cite this: Chem. Sci., 2019, 10, 5275

๑ All publication charges for this article have been paid for by the Royal Society of Chemistry

Received 30th January 2019

Accepted 16th April 2019

DOI: $10.1039 / c 9 s c 00554 d$

rsc.li/chemical-science

\section{Exploiting the trifluoroethyl group as a precatalyst ligand in nickel-catalyzed Suzuki-type alkylations $\uparrow$}

\author{
Yi Yang, (D) *a Qinghai Zhou, ${ }^{\mathrm{b}}$ Junjie Cai, ${ }^{\mathrm{a}}$ Teng Xue, ${ }^{\mathrm{c}}$ Yingle Liu, ${ }^{a}$ Yan Jiang, ${ }^{\text {a }}$ \\ Yumei Su, ${ }^{a}$ Lungwa Chung (D) and David A. Vicic ${ }^{\star c}$
}

We report herein the exploitment of the partially fluorinated trifluoroethyl as precatalyst ligands in nickelcatalyzed Suzuki-type alkylation and fluoroalkylation coupling reactions. Compared with the $\left[\mathrm{L}_{n} \mathrm{Ni}{ }^{\prime \prime}(\operatorname{aryl})(\mathrm{X})\right]$ precatalysts, the unique characters of bis-trifluoroethyl ligands imparted precatalyst [(bipy) $\left.\mathrm{Ni}\left(\mathrm{CH}_{2} \mathrm{CF}_{3}\right)_{2}\right]$ with bench-top stability, good solubilities in organic media and interesting catalytic activities. Preliminary mechanistic studies reveal that an eliminative extrusion of a vinylidene difluoride (VDF, $\mathrm{CH}_{2}=\mathrm{CF}_{2}$ ) mask from [(bipy) $\mathrm{Ni}\left(\mathrm{CH}_{2} \mathrm{CF}_{3}\right)_{2}$ ] is a critical step for the initiation of a catalytic reaction.

\section{Introduction}

Transition metal catalyzed cross-coupling reactions have advanced organic synthesis in the last few decades and have become powerful tools for the generation of molecular complexity. ${ }^{1}$ Substantial effort has been devoted to identifying general and robust transition metal catalytic systems for reaction methodology research and chemical production improvement. A prominent example is the development of SuzukiMiyaura coupling systems, which now employ a diverse combinations of transition-metals, supporting ligands, and coupling partners to construct $\mathrm{C}\left(\mathrm{sp}^{2}\right)-\mathrm{C}\left(\mathrm{sp}^{2}\right)$ bonds. ${ }^{2}$ Although Pd catalysts operate with much success in this arena, ${ }^{3}$ the development of Ni-catalyzed protocols has been of interest because of the cost efficiency and complementary reactivities. ${ }^{4}$ For instance, Ni-catalyzed couplings are particularly useful for constructing synthetically challenging $\mathrm{C}\left(\mathrm{sp}^{2}\right)-\mathrm{C}\left(\mathrm{sp}^{3}\right)$ linkages, ${ }^{5-7}$ due to the facile oxidation of low-valent nickel by $\mathrm{C}\left(\mathrm{sp}^{3}\right)$ centered electrophiles and the suppression of undesired $\beta$ hydrogen eliminations at nickel. ${ }^{\mathbf{4} 8}$ One of the most successful catalysts for nickel-catalyzed coupling reactions is derived from the [(bipyridine)nickel] motif which has been widely employed for both traditional cross-coupling and photoredox catalysis. ${ }^{5-7}$ However, it should be noted that the conventional [(bipyridine)

\footnotetext{
${ }^{a}$ Key Laboratory of Green Catalysis of Higher Education Institutes of Sichuan, School of Chemistry and Environmental Engineering, Sichuan University of Science \& Engineering, 180 Xueyuan Street, Huixing Lu, Zigong, Sichuan 643000, China. E-mail: yangyiyoung@163.com

${ }^{b}$ Shenzhen Grubbs Institute and Department of Chemistry, Southern University of Science and Technology, Shenzhen 518055, China. E-mail: oscarchung@sustc.edu.cn ${ }^{c}$ Department of Chemistry, Lehigh University, 6 E. Packer Ave., Bethlehem, PA 18015, USA. E-mail: vicic@lehigh.edu

$\dagger$ Electronic supplementary information (ESI) available. CCDC 1436475. For ESI and crystallographic data in CIF or other electronic format see DOI: 10.1039/c9sc00554d
}

nickel] systems characterized by a combination of $\mathrm{Ni}^{0}$ catalysts or inorganic $\mathrm{Ni}^{\mathrm{II}}$ salts with bipyridyl ligand still suffer from some unneglectable limitations: (i) commonly used $\mathrm{Ni}^{0}$ sources for catalysis are expensive and air-sensitive, thus hindering their use out of glovebox for large-scale synthesis; (ii) the low solubility of inorganic $\mathrm{Ni}^{\mathrm{II}}$ salts complicates the heteroleptic coordination of exogenous supporting ligands which could have deleterious effects on reaction outcomes.

In this context, the development of robust nickel-based precatalysts in which the metallic cores are preligated with privileged ligands is highly desirable and constitutes a viable solution to address the above-mentioned limitations. ${ }^{9}$ Recently, the carbon-bound nickel precatalysts have exerted powers in a variety of coupling reactions as alternatives to the conventional $\left[\mathrm{L}_{n} \mathrm{NiX}_{2}\right]$ precatalysts $(\mathrm{L}=\mathrm{P}$ or $\mathrm{N}$ ligands $) .{ }^{10}$ Notably, many previously reported carbon-bound $\mathrm{Ni}$ precatalysts $\left[\mathrm{L}_{n} \mathrm{Ni}(\mathrm{X})(\mathrm{R})\right]$ feature sterically bulky ligands ( $\mathrm{R}=o$-tolyl, mesityl, 1-naphthyl), or highly stabilizing motifs $\left(\mathrm{R}=\eta^{3}\right.$-allyl, $\left.\eta^{5}-\mathrm{Cp}\right)$ for sheltering reactive organometallic nickel cores (Fig. 1-A). ${ }^{\mathbf{1 0}}$ Considering that fluoroalkyl ligands are known to confer enhanced stability to metal complexes relative to their non-fluorinated alkyl counterparts owing to fluorine's unique electronic and steric properties, ${ }^{\mathbf{1 1 - 1 3}}$ we wondered whether the incorporation of selected fluoroalkyl moieties could support novel nickel-based precatalysts and render new catalytic activities for use in synthetic methods development (Fig. 1-B). Herein, we describe the synthesis of such a fluoroalkyl-bound nickel precatalyst and demonstrate its use in $\mathrm{C}\left(\mathrm{sp}^{2}\right)-\mathrm{C}\left(\mathrm{sp}^{3}\right)$ Suzuki-type coupling reactions.

\section{Result and discussion}

At the outset, we began the rational design of precatalyst based on the principles of utilizing short fluoroalkyl and bipyridine as supporting ligands for atomic economy and $\mathrm{C}\left(\mathrm{sp}^{2}\right)-\mathrm{C}\left(\mathrm{sp}^{3}\right)$ 
A. Well-defined carbon-ligated nickel precatalysts

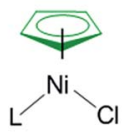

$L=I M e s$

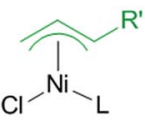

$\mathrm{R}^{\prime}=\mathrm{H}$ or $\mathrm{Ph}$; $\mathrm{L}=\mathrm{dppf}, \mathrm{IPr}$

B. Fluoroalkyl-bound Ni-based precatalyst for $\mathrm{C}\left(s p^{2}\right)-\mathrm{C}\left(s p^{3}\right)$ couplings

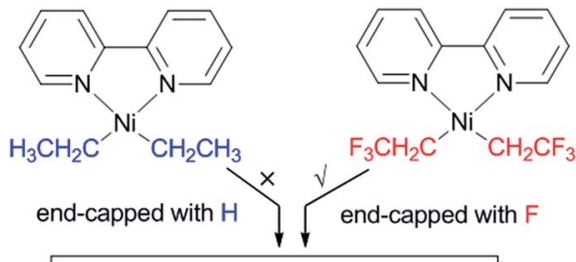

Suzuki-type $\mathrm{C}\left(s p^{2}\right)-\mathrm{C}\left(s p^{3}\right)$ couplings (novel precatalyst)

Fig. 1 Strategy for the development of fluoroalkyl-bound nickel precatalyst.

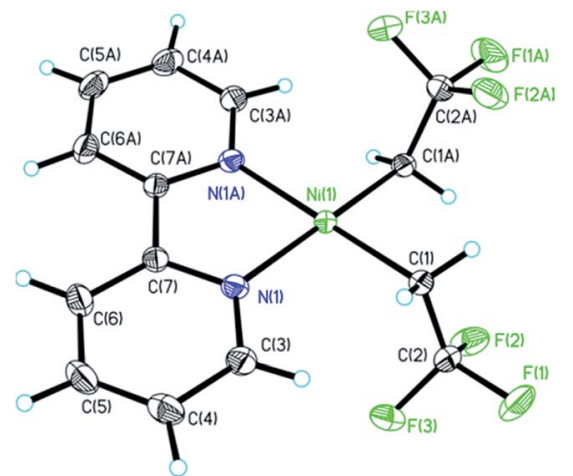

Fig. 2 ORTEP diagram of precatalyst [(bipy) $\left.\mathrm{Ni}\left(\mathrm{CH}_{2} \mathrm{CF}_{3}\right)_{2}\right] 2$.

coupling reaction efficiency. Specifically, the short and partially fluorinated $\mathrm{CF}_{3} \mathrm{CH}_{2}$ group was selected as supporting ligand (analogue of ethyl group but end-capped with fluorines) which was anticipated to render distinctive thermostability and reactivities versus both the hydrocarbonated [(bipy) $\left.\mathrm{Ni}\left(\mathrm{CH}_{2} \mathrm{CH}_{3}\right)_{2}\right]^{14}$ and perfluorinated [(bipy) Ni $\left.\left(\mathrm{CF}_{2} \mathrm{CF}_{3}\right)_{2}\right]^{12 g}$ counterparts (Fig. 1B, bipy $=2,2^{\prime}$-bipyridine). Gratifyingly, the reaction of $\left[\mathrm{Ni}(\mathrm{COD})_{2}\right]$, $\mathrm{CF}_{3} \mathrm{CH}_{2} \mathrm{I}$, and 2,2-bipyridine furnished [(bipy) $\left.\mathrm{Ni}\left(\mathrm{CH}_{2} \mathrm{CF}_{3}\right)_{2}\right] 2$ in $41 \%$ isolated yield (eqn (1)) presumably via an interesting ligand redistribution ${ }^{12 c, 15}$ of the intermediate [(bipy) $\left.\mathrm{Ni}_{(}\left(\mathrm{CH}_{2} \mathrm{CF}_{3}\right)(\mathrm{I})\right] \mathbf{1}$. The solubility of complex 2 in benzene facilitated its isolation from the nickel halide co-products 3 . The ${ }^{19} \mathrm{~F}$ NMR spectra of 2 exhibited a triplet at $\delta-47.98 \mathrm{ppm}$, demonstrating the presence of $\mathrm{CH}_{2} \mathrm{CF}_{3}$ groups and their bonding to $\mathrm{Ni}$ core. Dark red crystals of 2 can be grown from THF/pentane and are air-stable at room temperature for several weeks.

$$
\begin{aligned}
& \mathrm{Ni}(\mathrm{COD})_{2}+\text { bipy } \stackrel{\mathrm{CF}_{3} \mathrm{CH}_{2} \mathrm{I}}{\longrightarrow}\left[(\text { bipy }) \mathrm{Ni}\left(\mathrm{CH}_{2} \mathrm{CF}_{3}\right)(\mathrm{I})\right] \\
& 1 \\
& \begin{array}{r}
1 / 2 \text { (bipy) } \mathrm{Ni}\left(\mathrm{CH}_{2} \mathrm{CF}_{3}\right)_{2} \\
241 \% \text { isolated yield }
\end{array} \quad \begin{array}{c}
1 / 2 \text { (bipy) } \mathrm{Nil}_{2} \quad 3 \\
\text { insoluble in benzene }
\end{array}
\end{aligned}
$$

X-ray diffraction analysis of 2 confirmed the ligation of two $\mathrm{CH}_{2} \mathrm{CF}_{3}$ groups at nickel (Fig. 2). Complex 2 featured a square planar arrangement at the $\mathrm{Ni}^{\mathrm{II}}$ core with a rough linear trans $\mathrm{N}-$ $\mathrm{Ni}-\mathrm{C}$ linkage (bond angle: $177.4(2)$ and $\left.177.8(2)^{\circ}\right)$. In contrast, more striking distortions were found in the previously reported and related complexes [(bipy)Ni( $\left.\left(\mathrm{CF}_{3}\right)_{2}\right] \mathbf{4}$ (trans $\mathrm{N}-\mathrm{Ni}-\mathrm{C}$ bond angles: $165.1(2)^{\circ}$ and $\left.159.7(2)^{\circ}\right)$ and [(bipy) $\left.\mathrm{Ni}\left(\mathrm{CF}_{2} \mathrm{CF}_{3}\right)_{2}\right] \mathbf{5}$ (both at $\left.152.2^{\circ}\right),{ }^{12 g, 12 i}$ indicating fewer steric and electronic repulsions of the $\mathrm{CH}_{2} \mathrm{CF}_{3}$ chains in 2 compared to the perfluorinated derivatives. Interestingly, Ni-C distances of 2 (1.944(5) and $1.942(4) \AA)$ are substantially longer than those of 4 (1.872(6) and 1.883(6) $\AA$ ) and 5 (1.910(6) and 1.911(6) $⿱$ ). . Besides, the value of $\mathrm{C}(2)-\mathrm{F}(3)$ bond length [1.366(6) $\AA$, trans coplanar to $\mathrm{C}(1)-\mathrm{Ni}$ bond] was clearly larger than the others two carbon-fluorine bonds [C(2)-F(1) 1.346(5) $⿱$; C (2)-F(2) 1.342(6) $\AA]$ which implied the possibile use of $\beta$-fluorine elimination for further coupling reaction development.

Although we did not obtain the one fluoroalkyl accommodated nickel complex [(bipy)Ni $\left.\left(\mathrm{CH}_{2} \mathrm{CF}_{3}\right)(\mathrm{I})\right] \mathbf{1}$ which showed more structural similarities to the reported [(bipy) $\mathrm{Ni}(o$-tolyl $) \mathrm{Cl}]$ precatalyst, ${ }^{14 b}$ we presumed that $\beta$-fluorine elimination ${ }^{16}$ of [(bipy) $\left.\mathrm{Ni}\left(\mathrm{CH}_{2} \mathrm{CF}_{3}\right)_{2}\right] 2$ hinted by the C-F bond length analysis could be leveraged for the in situ generation of [(bipy) $\left.\mathrm{Ni}(\mathrm{F})\left(\mathrm{CH}_{2} \mathrm{CF}_{3}\right)\right]$ 2a with concurrent extrusion of vinylidenedifluoride $\left(\mathrm{CH}_{2}=\mathrm{CF}_{2}\right)$. Notably, the Ni-F structural motif of intermediate 2a was supposed to facilitate the transmetalation of arylboronic acids towards nickel according to a recent example of base-free Suzuki coupling. ${ }^{4 g}$ Furthermore, the bis-trifluoroethyl structural motifs of [(bipy) $\left.\mathrm{Ni}\left(\mathrm{CH}_{2} \mathrm{CF}_{3}\right)_{2}\right] 2$ entails the bench-top stability and excellent solubility in organic solvents which is of vital importance for developing nickelbased precatalysts. ${ }^{9,10}$

With [(bipy) $\left.\mathrm{Ni}\left(\mathrm{CH}_{2} \mathrm{CF}_{3}\right)_{2}\right] 2$ in hand, we initially assessed it as a precatalyst for the Suzuki-type coupling between $\mathrm{CF}_{3} \mathrm{CH}_{2} \mathrm{I}$ and arylboronic acids for $\mathrm{C}\left(\mathrm{sp}^{2}\right)-\mathrm{C}\left(\mathrm{sp}^{3}\right)$ bonding. Based upon previously established $\mathrm{Ni}$-catalyzed trifluoroethylation conditions,${ }^{17}$ we were pleased to find that coupling products can be obtained in excellent yields at $80{ }^{\circ} \mathrm{C}$ with $5 \mathrm{~mol} \%$ catalyst loading using $\mathrm{K}_{3} \mathrm{PO}_{4}$ as a base and DME as a solvent (Table 1, entry 1). Use of other solvents decreased the yields, and only polar non-protic DMSO solvent was comparatively effective. Furthermore, the use of $\mathrm{K}_{3} \mathrm{PO}_{4}$ was critical to the success of the coupling reaction and suppressing dehydrofluorination of the final products (for details, see ESI Tables S1 and S2 $\dagger$ ). The commercialized [(TMEDA)Ni(o-tolyl $) \mathrm{Cl}]^{10 e, 10 f}$ bearing modular TMEDA was found to be less efficient (yield 35\%) with using the privileged bipyridine as the leading supporting ligand (Table 1 , entry 2). In contrast, the bipyridine preligated [(bipy)Ni(o-tolyl) 
Table 1 Survey of reaction conditions ${ }^{a}$

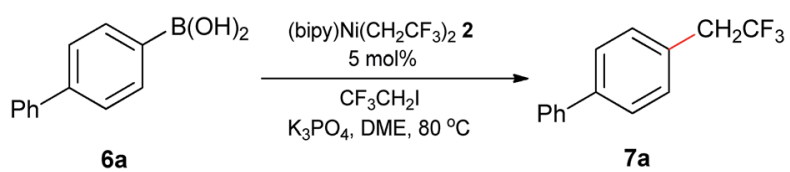

\begin{tabular}{|c|c|c|}
\hline Entry & Variation from standard conditions & Isolated yield \\
\hline 1 & None & $93 \%$ \\
\hline 2 & [(TMEDA)Ni(o-tolyl)Cl] $(5.0 \mathrm{~mol} \%)$ and 2,2-bipyridine $(5.0 \mathrm{~mol} \%)$ instead of 2 & $35 \%$ \\
\hline 3 & [(bipy) $\mathrm{Ni}(o$-tolyl $) \mathrm{Cl}](5.0 \mathrm{~mol} \%)$ instead of 2 & $78 \%$ \\
\hline 4 & {$[(\mathrm{dppf}) \mathrm{Ni}(o$-tolyl $) \mathrm{Cl}](5.0 \mathrm{~mol} \%)$ instead of 2} & $25 \%$ \\
\hline 5 & {$\left[\mathrm{Ni}(\mathrm{COD})_{2}\right](5.0 \mathrm{~mol} \%)$ and 2,2-bipyridine $(5.0 \mathrm{~mol} \%)$ instead of 2} & $40 \%$ \\
\hline 6 & {$\left[(\right.$ bipy $\left.) \mathrm{NiEt}_{2}\right](5.0 \mathrm{~mol} \%)$ instead of 2} & $13 \%$ \\
\hline 7 & {$\left[(\mathrm{MeCN})_{2} \mathrm{Ni}\left(\mathrm{CF}_{2} \mathrm{CF}_{3}\right)_{2}\right](5.0 \mathrm{~mol} \%)$ and 2,2-bipyridine $(5.0 \mathrm{~mol} \%)$ instead of 2} & $55 \%$ \\
\hline 8 & {$\left[(\mathrm{MeCN})_{2} \mathrm{Ni}\left(\mathrm{CF}_{3}\right)_{2}\right](5.0 \mathrm{~mol} \%)$ and 2,2-bipyridine $(5.0 \mathrm{~mol} \%)$ instead of 2} & $51 \%$ \\
\hline 6 & $2.5 \mathrm{~mol} \%$ loading of precatalyst 2 & $91 \%\left(83 \%{ }^{b}\right)$ \\
\hline 7 & $1.0 \mathrm{~mol} \%$ loading of precatalyst 2 & $79 \%$ \\
\hline
\end{tabular}

$\mathrm{Cl}]^{14 b}$ bearing the privileged $o$-tolyl ligand improved the coupling yield to $78 \%$ but was still inferior to that of [(bipy) $\left.\mathrm{Ni}\left(\mathrm{CH}_{2} \mathrm{CF}_{3}\right)_{2}\right]$. These results demonstrated the importances of supporting ligation groups of both trifluoroethyl and bipyridine in the structural motif of $\left[(\right.$ bipy $\left.) \mathrm{Ni}\left(\mathrm{CH}_{2} \mathrm{CF}_{3}\right)_{2}\right]$ (Table 1, entries 2$3)$. Even the classical $[(\mathrm{dppf}) \mathrm{Ni}(o \text {-tolyl }) \mathrm{Cl}]^{\mathbf{1 0 c}}$ or $\left[\mathrm{Ni}(\mathrm{COD})_{2}\right] /$

Table 2 Substrate scope of (hetero)arylboronic acid partners ${ }^{a}$

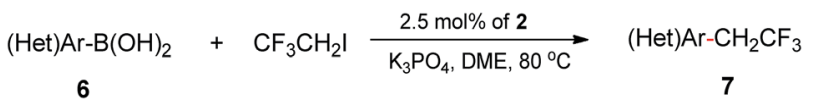<smiles>COc1ccc(CC(F)(F)F)cc1</smiles>

$7 c, 86 \%^{b}$<smiles>CC(C)(Oc1ccc(CC(F)(F)F)cc1)C(F)(F)F</smiles>

$7 d, 83 \%^{b}$<smiles>FC(F)(F)Cc1ccc2c(c1)OCCO2</smiles>

$7 e, 80 \%$ b<smiles>O=Cc1ccc(CC(F)(F)F)cc1</smiles>

7f, $70 \%{ }^{\mathrm{b}}$<smiles>CC(=O)c1ccc(CC(F)(F)F)cc1</smiles>

$7 g, 74 \%{ }^{b}$<smiles>CC(=O)c1ccc(CC(F)(F)F)cc1</smiles>

$7 h, 80 \%^{b}$<smiles>N#Cc1ccc(CC(F)(F)F)cc1</smiles>

$7 \mathrm{i}, 72 \%^{\mathrm{b}}$<smiles>O=Cc1cccc(CC(F)(F)F)c1</smiles>

$7 \mathrm{j}, 48 \%{ }^{\mathrm{b}}$<smiles>CC(=O)c1cccc(CC(F)(F)F)c1</smiles>

$7 \mathbf{k}, 67 \%$<smiles>CC(=O)c1cccc(CC(F)(F)F)c1</smiles>

$71,63 \%^{\mathrm{b}}$<smiles>N#Cc1cccc(CC(F)(F)F)c1</smiles>

$7 \mathrm{~m}, 44 \%^{\mathrm{b}}$<smiles>FC(F)(F)Cc1cccc(-c2ccccc2)c1</smiles>

7 n, $74 \%^{b}$<smiles>COc1ncccc1CC(F)(F)F</smiles>

$70,78 \%$ b<smiles>FC(F)(F)Cc1ccnc2ccccc12</smiles>

$7 p, 82 \%$ b<smiles>FC(F)(F)Cc1cccc2ccccc12</smiles>

$7 q, 70 \%{ }^{\mathrm{c}}(36 \%)$<smiles>FC(F)(F)Cc1ccc2ccccc2c1</smiles>

$7 \mathrm{r}, 87 \%^{\mathrm{c}}(42 \%)$<smiles>CC(C)OC(=O)C(C)(C)Oc1ccc(C(=O)c2ccc(CCF)cc2)cc1</smiles>

$7 \mathrm{~s}, 61 \%^{\mathrm{b}}$ (Fenofibrate analogue)<smiles>CCOC(=O)C(C)(C)Oc1ccc(CF)cc1</smiles>

$7 \mathrm{t}, 44 \%{ }^{\mathrm{b}, \mathrm{d}}$ (Clofibrate analogue)

\footnotetext{
${ }^{a}$ General conditions: (hetero)arylboronic acid $(0.6 \mathrm{mmol}), \mathrm{CF}_{3} \mathrm{CH}_{2} \mathrm{I}(0.4 \mathrm{mmol})$, base $(0.8 \mathrm{mmol}), 2.5 \mathrm{~mol} \%$ precatalyst loading, DME $(2.0 \mathrm{~mL})$, $80{ }^{\circ} \mathrm{C}$. ${ }^{b}$ Isolated yield. ${ }^{c}$ Yield determined by ${ }^{19} \mathrm{~F}$ NMR spectroscopy using $\mathrm{PhCF}_{3}$ as an internal standard due to the volatility of naphthalene products. Data in parentheses refer to yields of isolated products. ${ }^{d} 5.0 \mathrm{~mol} \%$ precatalyst loading.
} 
bipyridine $^{\mathbf{1 8}}$ combined system gave unsatisfactory yield (25$40 \%$ ) compared with the use of 2 (Table 1, entries 4-5). For further demonstrating the distinctive role of partially fluorinated trifluoroethyl ligand, we compared its catalytic performance with those surrogating [(bipy) $\left.\mathrm{NiEt}_{2}\right]{ }^{14 c}$ [(bipy) $\left.\mathrm{Ni}\left(\mathrm{CF}_{2} \mathrm{CF}_{3}\right)_{2}\right]^{12 i}$ and [(bipy)Ni( $\left.\left(\mathrm{CF}_{3}\right)_{2}\right]^{12 i}$ (Table 1, entries 6-8). It was found that these fully hydrocarbonated and fluorinated counterpart complexes can not furnish comparable catalytic outcomes. Gratifyingly, the tests of decreasing the precatalyst loading and gram-scale synthesis also provided the coupling product in comparatively good yields (Table 1, entries 6-7). These results demonstrated proof-in-principle of the excellent catalytic efficiency of precatalyst 2 for the targeted Suzuki-type couplings.

Under the optimized conditions, a wide array of arylboronic acid coupling partners were found to successfully participate in the Suzuki-type trifluoroethylation catalyzed by 2 (Table 2). Both the electron-donating and electron-withdrawing groups substituted arylboronic acids were competent substrates and gave the desired product in moderate to good yield. Broad functional groups were well tolerated, including ethers (7c-7e), aldehydes (7f, $7 \mathbf{j})$, enolizable ketones $(\mathbf{7 g}, \mathbf{7 k})$, esters $(\mathbf{7 h}, \mathbf{7} \mathbf{l})$ and nitriles $(7 \mathbf{i}, 7 \mathbf{m})$. Notably, the nitrogen-containing heterocyclic boronic acids (7o, $7 \mathbf{p}$ ) proceeded smoothly with good yields despite the potential strong binding affinity of the nitrogen atoms with $\mathrm{Ni}$. To further exhibit the synthetic practicality of our precatalyst and trifluoroethylation protocol, the late-stage modifications of fenofibrate and clofibrate (drugs against cardiovascular disease) were accomplished (7s, 7t). Therefore, this synthetic strategy should provide important opportunities for making more diverse biologically active molecules.

Further demonstration of the privileged catalytic utilities of precatalyst [(bipy)Ni( $\left.\mathrm{CH}_{2} \mathrm{CF}_{3}\right)_{2}$ ] 2 was showcased by several types of $\mathrm{C}\left(\mathrm{sp}^{2}\right)-\mathrm{C}\left(\mathrm{sp}^{3}\right)$ Suzuki-type alkylations. Iodoethane (8), 3-iodooxetane (9), ethyl bromoacetate (10), allyl bromide (11), (4,4,4-trifluoro-3-iodobutyl)benzene (12a), $\mathrm{HCF}_{2} \mathrm{CH}_{2} \mathrm{I}$ (12b) and $\mathrm{FCH}_{2} \mathrm{CH}_{2} \mathrm{I}(\mathbf{1 2 c})$ were found to successfully couple with a series of arylboronic acids ranging from electron-poor and electron-rich types (Table 3). The encouraging results showed

Table 3 Versatility of precatalyst 2 for aryl-alkyl cross-coupling reactions ${ }^{a}$

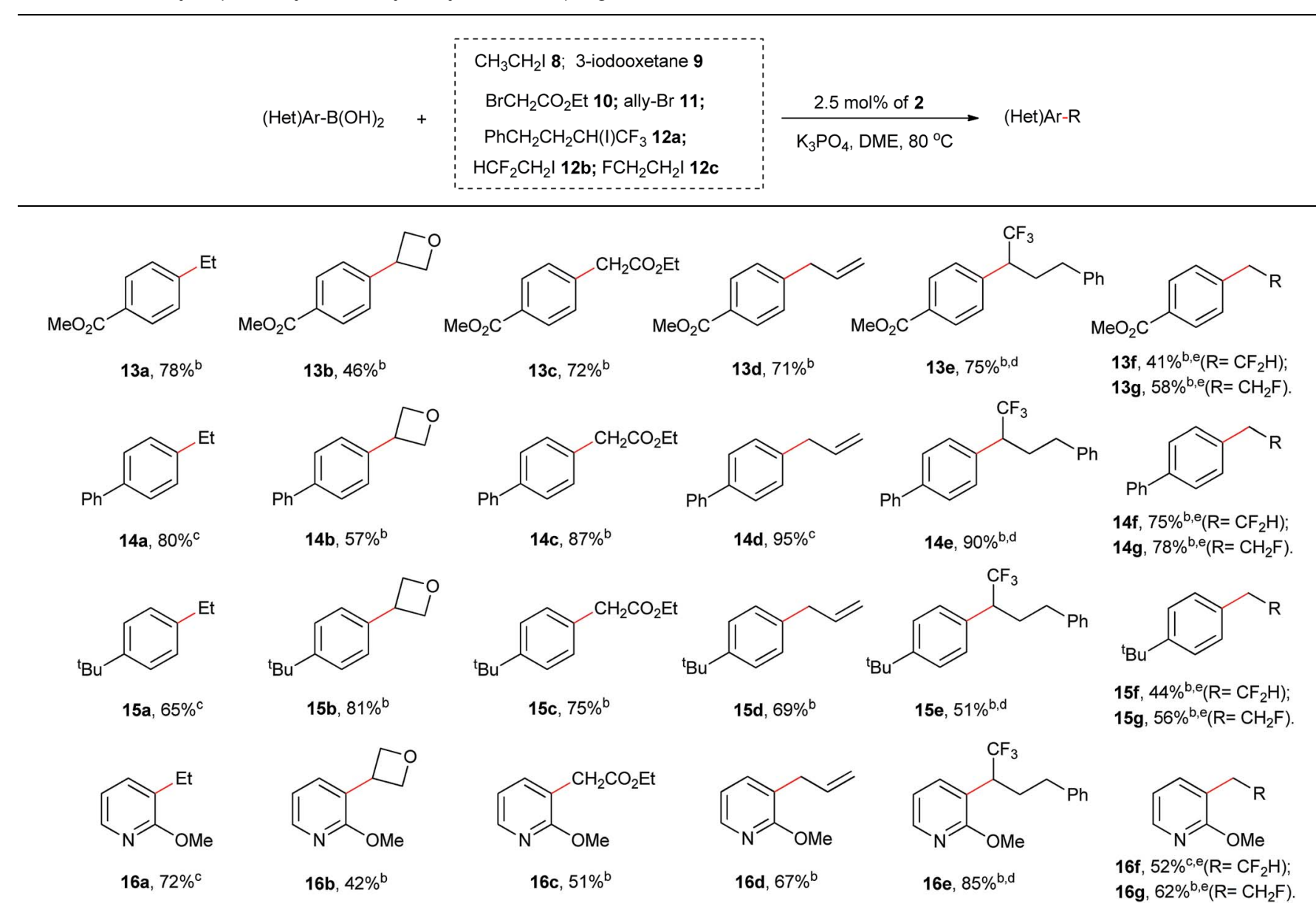

${ }^{a}$ General conditions: (hetero)arylboronic acid ( $\left.0.6 \mathrm{mmol}\right)$, the indicated $\mathrm{R}-\mathrm{X}(0.4 \mathrm{mmol})$, base $(0.8 \mathrm{mmol}), 2.5 \mathrm{~mol} \%$ precatalyst loading, DME $(2.0$ $\mathrm{mL}$ ), $80{ }^{\circ} \mathrm{C}$. ${ }^{b}$ Isolated yield. ${ }^{c}$ Yield determined by ${ }^{1} \mathrm{H}$ NMR spectroscopy using $\mathrm{Cl}_{2} \mathrm{CHCHCl}_{2}$ as an internal standard due to the difficulties in separation of product from deboronative byproduct. ${ }^{d}$ Using 5.0 mol\% precatalyst loading and DMSO as the solvent instead of DME. ${ }^{e}$ Using $5.0 \mathrm{~mol} \%$ precatalyst loading. 
that these primary and secondary alkyl halides were readily compatible with this catalytic alkylation, regardless of the possible $\beta-\mathrm{H}$ or $\beta-\mathrm{F}$ elimination problems. ${ }^{8 a}$ Furthermore, the active allyl group can be coupled with the aromatic groups without detection of the migration of double bond (13d). ${ }^{7}$

The success of precatalyst 2 for the Suzuki-type alkylations further encouraged us to investigate the reaction mechanism. At the start, we intended to determine whether the activation mode of [(bipy)Ni( $\left.\left.\mathrm{CH}_{2} \mathrm{CF}_{3}\right)_{2}\right]$ was consistent with our $\beta$-fluorine elimination hypothesis. The precatalyst could undergo $\beta$-fluorine elimination to afford [(bipy) $\left.\mathrm{Ni}(\mathrm{F})\left(\mathrm{CH}_{2} \mathrm{CF}_{3}\right)\right] \mathbf{2 a}$ with extrusion of $\mathrm{CH}_{2}=\mathrm{CF}_{2}$, or alternatively undergo reductive elimination like the analogous $\left[(\text { bipy }) \mathrm{Ni}\left(\mathrm{CH}_{2} \mathrm{CH}_{3}\right)_{2}\right]^{14}$ to generate a $\left[\left(\right.\right.$ bipy)Ni(0)] species and $\mathrm{CF}_{3} \mathrm{CH}_{2} \mathrm{CH}_{2} \mathrm{CF}_{3}$. Heating precatalyst 2 at elevated temperature indicated the clear formation of $\mathrm{CH}_{2}=\mathrm{CF}_{2}$ rather than $\mathrm{CF}_{3} \mathrm{CH}_{2} \mathrm{CH}_{2} \mathrm{CF}_{3}$ through continuous ${ }^{1} \mathrm{H}$ and ${ }^{19} \mathrm{~F}$ NMR monitoring (for details, see ESI Fig. S122 and S123 $\dagger$ ) which illustrated the direct formation of low-valent nickel species like [(bipy)Ni(0)] from [(bipy)Ni( $\mathrm{CH}_{2}-$ $\left.\left.\mathrm{CF}_{3}\right)_{2}\right] 2$ is less likely (Scheme 1-A). ${ }^{19}$ Additionally, the identification of $\mathrm{CH}_{2}=\mathrm{CF}_{2}$ and $\mathrm{Ar}-\mathrm{CH}_{2} \mathrm{CF}_{3}$ ( $\mathrm{Ar}=4$-biphenyl) in GC-MS and NMR analysis of the reactions in Table 3 (e.g. 14b, coupling between 4-biphenylboronic acid and 3-iodooxetane in Scheme 1B) revealed the important roles of the trifluoroethyl groups bound to nickel core (for details, see ESI Fig. S124, S125 and Table S5 $\dagger$ ). These results suggested that the first trifluoroethyl group functioned as the mask of the suggested active species [(bipy) $\left.\mathrm{Ni}(\mathrm{F})\left(\mathrm{CH}_{2} \mathrm{CF}_{3}\right)\right]$ 2a via a $\mathrm{CH}_{2}=\mathrm{CF}_{2}$ extrusion and the second trifluoroethyl moiety contributed as coupling partner for the formation of $\mathrm{Ar}-\mathrm{CH}_{2} \mathrm{CF}_{3}$. Interestingly, the finding of byproduct $\mathrm{CH}_{3} \mathrm{OCH}(\mathrm{Ar}) \mathrm{CH}_{2} \mathrm{OCH}_{3}$ and $\mathrm{ArCH}_{2} \mathrm{OCH}_{2} \mathrm{CH}_{2} \mathrm{OCH}_{3}$ (Scheme 1-B) illustrated plausible radical activation of DME

\section{A. NMR studies on the activation of precatalyst 2}

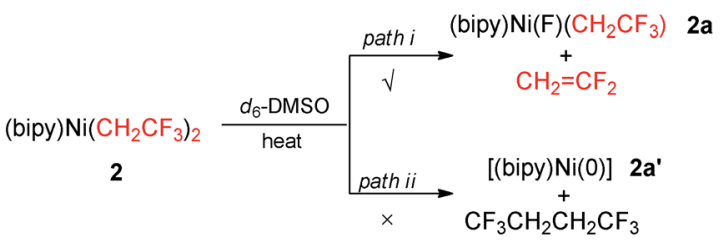

B. Probe the role of the nickel-bound trifluoroethyl as coupling partner

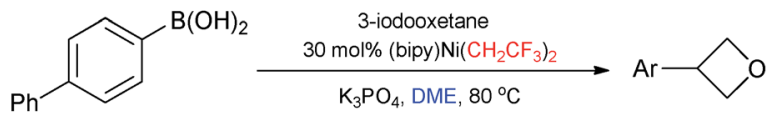

$$
\begin{gathered}
\text { GC-MS identified products: } \\
\mathrm{CH}_{2}=\mathrm{CF}_{2} \quad \mathrm{~m} / \mathrm{z} 64
\end{gathered}
$$

detected in the reaction system ( eliminative extrusion product) $\mathrm{CH}_{3} \mathrm{OCH}(\mathrm{Ar}) \mathrm{CH}_{2} \mathrm{OCH}_{3}$ $\mathrm{m} / \mathrm{z} 242$
(Ar= 4-biphenyl)

$$
\mathrm{Ar}-\mathrm{CH}_{2} \mathrm{CF}_{3} \quad \mathrm{~m} / \mathrm{z} 236
$$

isolated yield $11 \%$ $\mathrm{ArCH}_{2} \mathrm{OCH}_{2} \mathrm{CH}_{2} \mathrm{OCH}_{3}$ $\mathrm{m} / \mathrm{z} 242$
Scheme 1 Control experiments for identifying the role of trifluoroethyl ligands in precatalyst 2. through abstraction of ethereal $\alpha$-hydrogens by solvent-caged alkyl radicals. ${ }^{20}$

Next, a series of radical inhibition experiments were conducted to verify the possibilities of radical intermediacy (for details, see ESI Tables S8-S10 $\dagger$ ). It was found that the radical scavenger TEMPO shut down the coupling reactions completely when using the 3-iodooxetane or $\mathrm{CF}_{3} \mathrm{CH}_{2} \mathrm{I}$ as the alkyl electrophiles. Instead, TEMPO-alkyl (alkyl = 3-oxetanyl or trifluoroethyl) adducts $\mathbf{1 7}$ and $\mathbf{1 8}$ were observed in the GC-MS analysis, respectively. Also, when a radical-clock cyclopropanebased substrate was used, a few ring-opening products like the $\mathrm{CF}_{3} \mathrm{CH}_{2}$-merged product $\mathbf{2 0}$ and aryl-incorporated product $\mathbf{2 1}$ were identified. These experimental results suggested the involvement of $\mathrm{CF}_{3} \mathrm{CH}_{2}{ }^{\cdot}$ radicals (or R radicals) as well as arylbound nickel intermediates in the reaction profile.

With the above clues of reaction scenarios in hand, we conducted further interrogations on whether the reactions proceeded via a $\mathrm{Ni}^{0} / \mathrm{Ni}^{\mathrm{II}}$ or $\mathrm{Ni}^{\mathrm{I}} / \mathrm{Ni}^{\mathrm{III}}$ redox shuttle. The important findings of bis-trifluoroethyl ligands of 2 serving as $\mathrm{CH}_{2}=$ $\mathrm{CF}_{2}$ mask and operational ligand for producing $\mathrm{Ar}-\mathrm{CH}_{2} \mathrm{CF}_{3}$ inspired us to devise a stoichiometric reaction of complex 2 with 4-biphenylboronic acid as control experiment (Scheme 2A). The intermediate [(bipy) $\left.\mathrm{Ni}(\mathrm{F})\left(\mathrm{CH}_{2} \mathrm{CF}_{3}\right)\right] \mathbf{2 a}$ could be generated in situ under the reaction conditions which was supposed to further undergo a facile Ni-B transmetalation ${ }^{4 g}$ to deliver [(bipy)Ni(Ar) $\left.\left(\mathrm{CH}_{2} \mathrm{CF}_{3}\right)\right]$ 2b $(\mathrm{Ar}=4$-biphenyl). However, the putative [(bipy) $\left.\mathrm{Ni}(\mathrm{Ar})\left(\mathrm{CH}_{2} \mathrm{CF}_{3}\right)\right]$ intermediate did not proceed through a $\mathrm{Ni}(\mathrm{II}) / \mathrm{Ni}(0)$ reductive elimination ${ }^{\mathbf{1 0 e}}$ to furnish $\mathrm{Ar}-$ $\mathrm{CH}_{2} \mathrm{CF}_{3}$. In addition, $\mathrm{CF}_{3} \mathrm{CH}_{2} \mathrm{~F}$ and $\mathrm{CF}_{3} \mathrm{CH}_{2} \mathrm{CH}_{2} \mathrm{CF}_{3}$ were also not found which disfavored the scenario of $\mathrm{Ni}^{0}$ formation from the reductive elimination of $\mathbf{2 a}$ and $\mathbf{2}$. Taken together, these divalent organonickel intermediates (2, 2a and $\mathbf{2 b}$ ) were not productive for the corresponding $\mathrm{Ni}{ }^{\mathrm{II}} / \mathrm{Ni}^{0}$ reductive elimination under this current reaction system. Interestingly, the product

A. Stoichiometric reaction of 4-biphenylboronic acid with precatalyst 2

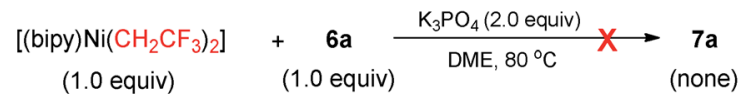

GC-MS identified products:
$\mathrm{CH}_{2}=\mathrm{CF}_{2} \quad \mathrm{~m} / \mathrm{z} 64$

detected in reaction system (evidence for eliminative extrusion)

Not detected

$\mathrm{Ar}-\mathrm{CH}_{2} \mathrm{CF}_{3}$ $\mathrm{CF}_{3} \mathrm{CH}_{2} \mathrm{~F}$
( $\mathrm{Ar}=4$-biphenyl)

$\mathrm{CF}_{3} \mathrm{CH}_{2} \mathrm{CH}_{2} \mathrm{CF}_{3}$

B. Trifluoroethylation catalyzed by a putative univalent [(bipy) $\left.\mathrm{Ni}^{\prime}(\mathrm{Br})\right]$

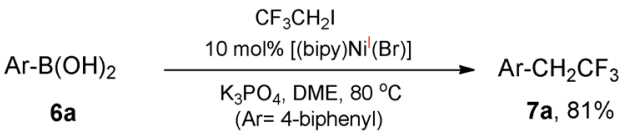

Scheme 2 Control experiments to support $\mathrm{Ni}^{\prime} / \mathrm{Ni}^{111}$ redox shuttle in the catalytic cycle. 
Ar- $\mathrm{CH}_{2} \mathrm{CF}_{3}$ was almost comparably efficiently obtained when the precatalyst 2 was replaced by the putative [(bipy) $\left.\mathrm{Ni}^{\mathrm{I}}(\mathrm{Br})\right]$ complex ${ }^{21}$ for the coupling between $\operatorname{ArB}(\mathrm{OH})_{2}$ and $\mathrm{CF}_{3} \mathrm{CH}_{2} \mathrm{I}$ (Scheme 2-B). These experimental results suggested that $\mathrm{a} \mathrm{Ni}^{\mathrm{I}}$ / $\mathrm{Ni}^{\mathrm{III}}$ catalytic cycle was highly likely to be superior to $\mathrm{Ni}^{\mathrm{O}} / \mathrm{Ni}^{\mathrm{II}}$ counterpart in the current reaction systems.

Based on the above-mentioned experimental results and relevant previous reports, ,, $\mathbf{6 , 1 3 , 2 2}_{\text {a }}$ plausible mechanism was proposed for these current cross-couplings (Scheme 3). The catalysis commences with an eliminative liberation of $\mathrm{CH}_{2}=$ $\mathrm{CF}_{2}$ mask and $\mathbf{2 a}$. Intermediate $\mathbf{2 a}$ is proposed to undergo transmetalation and subsequent abstraction of halogen atom from $\mathrm{R}-\mathrm{X}$ to afford (bipy) $\mathrm{Ni}^{\mathrm{III}}(\mathrm{Ar})\left(\mathrm{CH}_{2} \mathrm{CF}_{3}\right)(\mathrm{X})$ A. Reductive elimination of $\mathbf{A}$ has been fingerprinted by the formation of $\mathrm{Ar}-$ $\mathrm{CH}_{2} \mathrm{CF}_{3}$ and delivered a key catalytic species (bipy)Ni $\mathrm{Ni}^{\mathrm{I}}(\mathrm{X}) \mathbf{B}$. Upon the participation of $\mathbf{B}$ into the conventional $\mathrm{Ni}^{\mathrm{I}} / \mathrm{Ni}^{\mathrm{II}} / \mathrm{Ni}^{\mathrm{III}}$ catalytic cycle, the shuttles via transmetalation/oxidative addition $^{22} /$ reductive elimination provided efficient platform for the above described Suzuki-type $\mathrm{C}\left(\mathrm{sp}^{2}\right)-\mathrm{C}\left(\mathrm{sp}^{3}\right)$ alkylation couplings. ${ }^{23}$

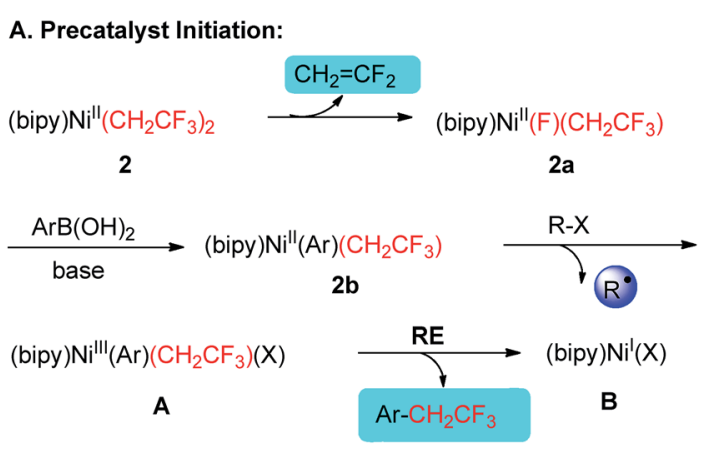

B. Side reactions of $\mathrm{R}$ radical intermediate:

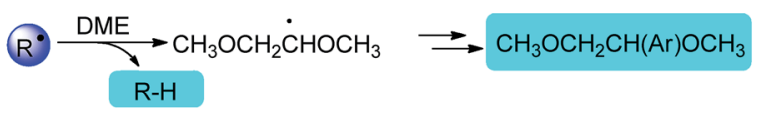

C. Possible Catalytic cycle ( $L=$ bipy):

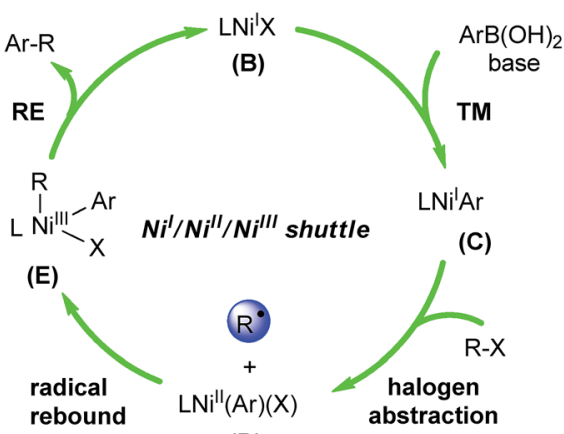

(D)

Scheme 3 Proposed reaction mechanism for Suzuki-type alkylation couplings based on control experiments. The shadow depicted species in precatalyst initiation and radical-relay side reactions were fingerprinted by GC-MS.

\section{Conclusions}

In conclusion, we demonstrated that the nickel-based precatalyst 2 [(bipy) $\left.\mathrm{Ni}\left(\mathrm{CH}_{2} \mathrm{CF}_{3}\right)_{2}\right]$ can be employed in Suzuki-type coupling reactions between (hetero)arylboronic acids and a variety of alkyl halides including several typical partially fluorinated alkyl halides bearing susceptible $\beta$-fluorine atoms (2-iodo-1,1,1-trifluoroethane and 12a-12c), leading to new $\mathrm{C}\left(\mathrm{sp}^{2}\right)-\mathrm{C}\left(\mathrm{sp}^{3}\right)$ linkages. Catalytic performance tests demonstrated the advantages of the trifluoroethyl ligand motifs in the precatalyst [(bipy)Ni( $\left.\left(\mathrm{CH}_{2} \mathrm{CF}_{3}\right)_{2}\right]$ versus several sibling perfluorinated and hydrocarbonated counterparts. ${ }^{24}$ The critical roles of trifluoroethyl groups of precatalyst 2 as both $\mathrm{CH}_{2}=\mathrm{CF}_{2}$ mask and triggering coupling-ligand in these nickel-catalyzed Suzuki-type alkylations were elucidated through mechanistic investigations. We believe that the initial success outlined here could prompt the utilization of more fluoroalkyl binding moieties for the development of new metal-based precatalysts with tailored activities. Further studies towards this endeavor and mechanistic details are underway in our laboratory, and the results will be reported in due course.

\section{Conflicts of interest}

We authors announce that there are no conflicts to declare.

\section{Acknowledgements}

We thank National Natural Science Foundation of China (21502131, 21672096, 21702095), Science \& Technology Department of Sichuan Province (2018JZ0061, 2018HH0128), Education Department of Sichuan Province (18CZ0024), Key Laboratory of Vanadium and Titanium of Sichuan Province (2018FTSZ03), Sichuan University of Science and Engineering (2017RCL03), Shenzhen Nobel Prize Scientists Laboratory Project (C17213101) and Office of Basic Energy Sciences of the U.S. Department of Energy (DE-SC0009363) for funding this work.

\section{Notes and references}

1 (a) C. S. Yeung and V. M. Dong, Chem. Rev., 2011, 111, 1215; (b) S. H. A. M. Leenders, R. Gramage-Doria, B. de Bruin and J. N. H. Reek, Chem. Soc. Rev., 2015, 44, 433; (c) J. Choi and G. C. Fu, Science, 2017, 356, 6334; (d) Q.-L. Zhou, Angew. Chem., Int. Ed., 2016, 55, 5352; (e) J. Twilton, C. Le, P. Zhang, M. H. Shaw, R. W. Evans and D. W. C. MacMillan, Nat. Rev. Chem., 2017, 1, 0052.

2 (a) A. Suzuki, Angew. Chem., Int. Ed., 2011, 50, 6722; (b) R. Martin and S. L. Buchwald, Acc. Chem. Res., 2008, 41, 1461; (c) S. R. Chemler, D. Trauner and S. J. Danishefsky, Angew. Chem., Int. Ed., 2001, 40, 4544.

3 (a) T. Ben Halima, W. Zhang, I. Yalaoui, X. Hong, Y.-F. Yang, K. N. Houk and S. G. Newman, J. Am. Chem. Soc., 2017, 139, 1311; (b) G. Meng, S. Shi and M. Szostak, ACS Catal., 2016, 6, 7335; (c) S. Handa, Y. Wang, F. Gallou and B. H. Lipshutz, 
Science, 2015, 349, 1087; (d) Z. Feng, Q.-Q. Min, X.-P. Fu, L. An and X. Zhang, Nat. Chem., 2017, 9, 918.

4 (a) C.-Y. Lin and P. P. Power, Chem. Soc. Rev., 2017, 46, 5347; (b) V. P. Ananikov, ACS Catal., 2015, 5, 1964; (c) J. Schmidt, J. Choi, A. T. Liu, M. Slusarczyk and G. C. Fu, Science, 2016, 354, 1265; (d) G. C. Fu, ACS Cent. Sci., 2017, 3, 692; (e) S. Z. Tasker, E. A. Standley and T. F. Jamison, Nature, 2014, 509, 299; (f) F.-S. Han, Chem. Soc. Rev., 2013, 42, 5270; $(g)$ C. A. Malapit, J. R. Bour, C. E. Brigham and M. S. Sanford, Nature, 2018, 563, 100.

5 (a) D. A. Everson, R. Shrestha and D. J. Weix, J. Am. Chem. Soc., 2010, 132, 920; (b) D. A. Everson, B. A. Jones and D. J. Weix, J. Am. Chem. Soc., 2012, 134, 6146; (c) A. C. Wotal and D. J. Weix, Org. Lett., 2012, 14, 1476; (d) K. M. M. Huihui, J. A. Caputo, Z. Melchor, A. M. Olivares, A. M. Spiewak, K. A. Johnson, T. A. DiBenedetto, S. Kim, L. K. G. Ackerman and D. J. Weix, J. Am. Chem. Soc., 2016, 138, 5016; (e) N. T. Kadunce and S. E. Reisman, J. Am. Chem. Soc., 2015, 137, 10480; (f) K. E. Poremba, N. T. Kadunce, N. Suzuki, A. H. Cherney and S. E. Reisman, J. Am. Chem. Soc., 2017, 139, 5684; (g) P. Zhang, C. C. Le and D. W. C. MacMillan, J. Am. Chem. Soc., 2016, 138, 8084; (h) C. Xu, W.-H. Guo, X. He, Y.-L. Guo, X.-Y. Zhang and X. Zhang, Nat. Commun., 2018, 9, 1170; (i) X. Wang, Y. Dai and H. Gong, Top. Curr. Chem., 2016, 374, 1; (j) X. Wang, G. Ma, Y. Peng, C. E. Pitsch, B. J. Moll, T. D. Ly, X. Wang and H. Gong, J. Am. Chem. Soc., 2018, 140, 14490; (k) J. Sheng, H.-Q. Ni, H.-R. Zhang, K.-F. Zhang, Y.-N. Wang and X.-S. Wang, Angew. Chem., Int. Ed., 2018, 57, 7634.

6 (a) Y.-L. Xiao, Q.-Q. Min, C. Xu, R.-W. Wang and X. Zhang, Angew. Chem., Int. Ed., 2016, 55, 5837; (b) Y.-L. Xiao, W.-H. Guo, G.-Z. He, Q. Pan and X. Zhang, Angew. Chem., Int. Ed., 2014, 53, 9909; (c) A. Joshi-Pangu, C.-Y. Wang and M. R. Biscoe, J. Am. Chem. Soc., 2011, 133, 8478; (d) Z. Lu, A. Wilsily and G. C. Fu, J. Am. Chem. Soc., 2011, 133, 8154; (e) Z. $\mathrm{Lu}$ and G. C. Fu, Angew. Chem., Int. Ed., 2010, 49, 6676; (f) N. A. Owston and G. C. Fu, J. Am. Chem. Soc., 2010, 132, 11908; $(g)$ S. L. Zultanski and G. C. Fu, J. Am. Chem. Soc., 2013, 135, 624; (h) Z. Zuo, H. Cong, W. Li, J. Choi, G. C. Fu and D. W. C. MacMillan, J. Am. Chem. Soc., 2016, 138, 1832; (i) J. Li, Y. Luo, H. W. Cheo, Y. Lan and J. Wu, Chem, 2019, 5, 192; (j) H. Yi, W. Mao and M. Oestreich, Angew. Chem., Int. Ed., 2019, 58, 3575; $(k)$ L. An, Y.-L. Xiao, Q.-Q. Min and X. Zhang, Angew. Chem., Int. Ed., 2015, 54, 9079; (l) N. D. Schley and G. C. Fu, J. Am. Chem. Soc., 2014, 136, 16588; $(m)$ Y. M. Su, G. S. Feng, Z. Y. Wang, Q. Lan and X. S. Wang, Angew. Chem., Int. Ed., 2015, 54, 6003; (n) J. Sheng, H.-Q. Ni, K.-J. Bian, Y. Li, Y.-N. Wang and X.-S. Wang, Org. Chem. Front., 2018, 5, 606.

7 (a) F. Juliá-Hernández, T. Moragas, J. Cornella and R. Martin, Nature, 2017, 545, 84; (b) F. Chen, K. Chen, Y. Zhang, Y. He, Y.-M. Wang and S. Zhu, J. Am. Chem. Soc., 2017, 139, 13929; (c) L. Peng, Y. Li, Y. Li, W. Wang, H. Pang and G. Yin, ACS Catal., 2018, 8, 310.

8 (a) A. Rudolph and M. Lautens, Angew. Chem., Int. Ed., 2009, 48, 2656; (b) X. Hu, Chem. Sci., 2011, 2, 1867; (c) A. Kaga and S. Chiba, ACS Catal., 2017, 7, 4697.
9 (a) N. Hazari, P. R. Melvin and M. M. Beromi, Nat. Rev. Chem., 2017, 1, 25; (b) L. M. Guard, M. Mohadjer Beromi, G. W. Brudvig, N. Hazari and D. J. Vinyard, Angew. Chem., Int. Ed., 2015, 54, 13352; (c) A. B. Dürr, H. C. Fisher, I. Kalvet, K.-N. Truong and F. Schoenebeck, Angew. Chem., Int. Ed., 2017, 56, 13431.

10 (a) E. A. Standley and T. F. Jamison, J. Am. Chem. Soc., 2013, 135, 1585; (b) C. M. Lavoie, P. M. MacQueen, N. L. RottaLoria, R. S. Sawatzky, A. Borzenko, A. J. Chisholm, B. K. V. Hargreaves, R. McDonald, M. J. Ferguson and M. Stradiotto, Nat. Commun., 2016, 7, 11073; (c) R. S. Sawatzky, M. J. Ferguson and M. Stradiotto, Synlett, 2017, 28, 1586; (d) N. H. Park, G. Teverovskiy and S. L. Buchwald, Org. Lett., 2014, 16, 220; (e) J. D. Shields, E. E. Gray and A. G. Doyle, Org. Lett., 2015, 17, 2166; (f) J. Magano and S. Monfette, ACS Catal., 2015, 5, 3120; $(g)$ P. M. MacQueen, J. P. Tassone, C. Diaz and M. Stradiotto, J. Am. Chem. Soc., 2018, 140, 5023; (h) A. J. Nett, S. Cañellas, Y. Higuchi, M. T. Robo, J. M. Kochkodan, M. T. Haynes, J. W. Kampf and J. Montgomery, ACS Catal., 2018, 8, 6606; (i) M. Mohadjer Beromi, G. Banerjee, G. W. Brudvig, N. Hazari and B. Q. Mercado, ACS Catal., 2018, 8, 2526.

11 (a) C. Ni and J. Hu, Chem. Soc. Rev., 2016, 45, 5441; (b) B. Lantaño, M. R. Torviso, S. M. Bonesi, S. Barata-Vallejo and A. Postigo, Coord. Chem. Rev., 2015, 285, 76; (c) H. Wang and D. A. Vicic, Synlett, 2013, 24, 1887; (d) D. O'Hagan, Chem. Soc. Rev., 2008, 37, 308.

12 (a) M. D. Kosobokov, A. Sandleben, N. Vogt, A. Klein and D. A. Vicic, Organometallics, 2018, 37, 521; (b) K. R. McGarry and D. A. Vicic, J. Fluorine Chem., 2017, 203, 206; (c) L. Xu and D. A. Vicic, J. Am. Chem. Soc., 2016, 138, 2536; (d) S. Yu, Y. Dudkina, H. Wang, K. V. Kholin, M. K. Kadi-rov, Y. H. Budnikova and D. A. Vicic, Dalton Trans., 2015, 44, 19443; (e) C.-P. Zhang, H. Wang, A. Klein, C. Biewer, K. Stirnat, Y. Yamaguchi, L. Xu, V. GomezBenitez and D. A. Vicic, J. Am. Chem. Soc., 2013, 135, 8141; (f) P. T. Kaplan, L. Xu, B. Chen, K. R. McGarry, S. Yu, H. Wang and D. A. Vicic, Organometallics, 2013, 32, 7552; (g) Y. Yamaguchi, H. Ichioka, A. Klein, W. W. Brennes-sel and D. A. Vicic, Organometallics, 2012, 31, 1477; (h) A. Klein, D. A. Vicic, C. Biewer, I. Kieltsch, K. Stirnat and C. Hamacher, Organometallics, 2012, 31, 5334; (i) Compounds $\mathbf{4}$ and $\mathbf{5}$ were theoretically modulated in ref. 12g. We used the combination of bipyridine and $(\mathrm{MeCN})_{2} \mathrm{Ni}\left(\mathrm{R}_{\mathrm{f}}\right)_{2}$ as the surrogate. The complexes $(\mathrm{MeCN})_{2} \mathrm{Ni}\left(\mathrm{R}_{\mathrm{f}}\right)_{2} \quad\left(\mathrm{R}_{\mathrm{f}}=\mathrm{CF}_{3}\right.$ or $\left.\mathrm{C}_{2} \mathrm{~F}_{5}\right)$ were synthesized according to our developed method (ref. 12e).

13 (a) N. M. Camasso and M. S. Sanford, Science, 2015, 347, 1218; (b) J. R. Bour, N. M. Camasso and M. S. Sanford, J. Am. Chem. Soc., 2015, 137, 8034; (c) J. R. Bour, N. M. Camasso, E. A. Meucci, J. W. Kampf, A. J. Canty and M. S. Sanford, J. Am. Chem. Soc., 2016, 138, 16105; (d) J. W. Schultz, K. Fuchigami, B. Zheng, N. P. Rath and L. M. Mirica, J. Am. Chem. Soc., 2016, 138, 12928; (e) M. B. Watson, N. P. Rath and L. M. Mirica, J. Am. Chem. Soc., 2017, 139, 35. 
14 Complex [(bipy)Ni $\left.\left(\mathrm{CH}_{2} \mathrm{CH}_{3}\right)_{2}\right]$ are known to be air-sensitive and eliminate the alkyl ligands (reductive elimination and $\beta$-eliminations) at temperatures close to room temperature, please see references: (a) T. Yamamoto and M. Abla, J. Organomet. Chem., 1997, 535, 209; (b) M. Uchino, K. Asagi, A. Yamamoto and S. Ikeda, J. Organomet. Chem., 1975, 84, 93; (c) A. Yamamoto, K. Morifuji, S. Ikeda, T. Saito, Y. Uchida and A. Misono, J. Am. Chem. Soc., 1965, 87, 4652.

15 Ligand redistribution processes are common in nickel chemistry, please see references: (a) Y. Takakazu, K. Teiji and Y. Akio, Bull. Chem. Soc. Jpn., 1981, 54, 2010; (b) S. Biswas and D. J. Weix, J. Am. Chem. Soc., 2013, 135, 16192; (c) T. Yamamoto, S. Wakabayashi and K. Osakada, J. Organomet. Chem., 1992, 428, 223.

16 For selected examples of nickel-catalyzed $\beta$-fluorine eliminations for synthetic methods development, see: $(a)$ T. Ichitsuka, T. Fujita, T. Arita and J. Ichikawa, Angew. Chem., Int. Ed., 2014, 53, 7564; (b) T. Ichitsuka, T. Fujita and J. Ichikawa, ACS Catal., 2015, 5, 5947; (c) Y. Lan, F. Yang and C. Wang, ACS Catal., 2018, 8, 9245; (d) Z. Lin, Y. Lan and C. Wang, ACS Catal., 2019, 9, 775.

17 (a) X. Zhang and C. Yang, Adv. Synth. Catal., 2015, 357, 2721; For some other related metal catalyzed trifluoroethylations: (b) Y. Zhao and J. Hu, Angew. Chem., Int. Ed., 2012, 51, 1033; (c) A. Liang, X. Li, D. Liu, J. Li, D. Zou, Y. Wu and Y. Wu, Chem. Commun., 2012, 48, 8273; (d) S. Xu, H.-H. Chen, J.-J. Dai and H.-J. Xu, Org. Lett., 2014, 16, 2306. 18 Although [(bipy)Ni( $\left.\left(\mathrm{CH}_{2} \mathrm{CF}_{3}\right)_{2}\right]$ could be generated in situ within the $\left[\mathrm{Ni}(\mathrm{COD})_{2}\right] /$ bipyridine trifluoroethylation systems, the deleterious effect of 1,5-cyclooctadiene (COD) on the current coupling can not be neglected. Please see related ref. $10 a, e \mathrm{~J}$. D. Shields, D. T. Ahneman, T. J. A. Graham and A. G. Doyle, Org. Lett., 2014, 16, 142, and .

19 The reductive eliminations of difluoroalkylnickel species were also proved to be challenging in the ref. $12 e$ and $13 c$.

20 When using $\mathrm{CF}_{3} \mathrm{CH}_{2} \mathrm{I}$ or $\mathrm{BrCH}_{2} \mathrm{CO}_{2}$ Et as electrophiles, we also found the formation of by product $\mathrm{R}-\mathrm{H}\left(\mathrm{R}=\mathrm{CF}_{3} \mathrm{CH}_{2}-\right.$ or EtOCOCH${ }_{2}^{-}$) which could be ascribed to the abstraction of ethereal $\alpha$-hydrogen in the DME solvent cages (for details, see ESI Tables S6 and S7 $\dagger$ ). For related references for radical reactions in solvent cage: $(a)$ D. A. Braden, E. E. Parrack and D. R. Tyler, Coord. Chem. Rev., 2001, 211, 279; (b) K. Michio, G. Michiko and Y. Masato, Bull. Chem. Soc. Jpn., 1987, 60, 295; (c) R. A. Sheldon and J. K. Kochi, J. Am. Chem. Soc., 1970, 92, 4395.

21 [(bipy) $\left.\mathrm{Ni}^{\mathrm{I}}(\mathrm{Br})\right]$ was prepared according to the synthetic method of $\left[(\mathrm{dppf}) \mathrm{Ni}^{(\mathrm{I})} \mathrm{Cl}\right]:(a)$ L. M. Guard, M. Mohadjer Beromi, G. W. Brudvig, N. Hazari and D. J. Vinyard, Angew. Chem., Int. Ed., 2015, 54, 13352. It was characterized by IR and XPS due to its bad solubility for single crystal formation (for details, see ESI $\dagger$ ). Very recently, Hazari group disclosed the synthesis of $\left[(\right.$ neocuproine $\left.){ }_{2} \mathrm{Ni}^{\mathrm{I}}\right](\mathrm{Cl})$ which had a similar skeleton: (b) M. Mohadjer Beromi, G. W. Brudvig, N. Hazari, H. M. C. Lant and B. Q. Mercado, Angew. Chem., Int. Ed., 2019, DOI: 10.1002/ anie. 201901866.

22 For selected example of radical-rebound oxidative addition of alkyl halide: (a) Z. Ruan, S. Lackner and L. Ackermann, Angew. Chem., Int. Ed., 2016, 55, 3153. If the radical-chain mechanism was operative, the cage-escaped radicals should dimerize via radical recombination. Also, we did not detect any radical dimerization products $(\mathrm{R}-\mathrm{R})$ in these experiments which could support a fast cage-rebound other than cage-escape process. For our recent report about the radical-rebound oxidative addition step in the nickel-catalyzed Suzuki-type fluoroethylation: $(b)$ Y. Yang, J. Cai, G. Luo, Y. Jiang, Y. Su, Y. Su, C. Li, Y. Zheng, J. Zeng and Y. Liu, Org. Chem. Front., 2019, DOI: 10.1039/ c9q000066f. For some seminal literatures for elucidating cage-rebound or cage-escape modes: ref. $15 b$ and $(c)$ J. Breitenfeld, J. Ruiz, M. D. Wodrich and X. Hu, J. Am. Chem. Soc., 2013, 135, 12004.

23 According to the recent reports about the catalytic activities of $\left[\mathrm{L}_{n} \mathrm{Ni}\right.$ I Ar], the catalytic shuttle started from the species $\left[\mathrm{L}_{n} \mathrm{Ni}^{\mathrm{I} X}\right]$ B via a transmetalation/oxidative addition/ reductive elimination sequence other than oxidative addition/transmetalation/reductive elimination order should be plausible. The observed inertness of [(bipy) $\mathrm{Ni}{ }^{\mathrm{I}} \mathrm{Br}$ ] towards $\mathrm{CF}_{3} \mathrm{CH}_{2} \mathrm{I}$ seemed to rule out the oxidative addition/transmetalation/reductive elimination sequence. For some references about related $\left[\mathrm{L}_{n} \mathrm{Ni}^{\mathrm{I}} \mathrm{Ar}\right]$ complexes: $(a)$ J. B. Diccianni, J. Katigbak, C. Hu and T. Diao, J. Am. Chem. Soc., 2019, 141, 1788; ref. 10i. More corroborative computational studies can be found in these references: (b) Z. Li, Y.-Y. Jiang and Y. Fu, Chem.-Eur. J., 2012, 18, 4345; (c) X. Lin and D. L. Phillips, J. Org. Chem., 2008, 73, 3680. For selected references that support $\mathrm{Ni}^{\mathrm{I}} / \mathrm{Ni}^{\mathrm{III}}$ catalytic shuttle: ref. $13 c$ and $d(d)$ G. D. Jones, J. L. Martin, C. McFarland, O. R. Allen, R. E. Hall, A. D. Haley, R. J. Brandon, T. Konovalova, P. J. Desrochers, P. Pulay and D. A. Vicic, J. Am. Chem. Soc., 2006, 128, 13175; (e) B. Zheng, F. Tang, J. Luo, J. W. Schultz, N. P. Rath and L. M. Mirica, J. Am. Chem. Soc., 2014, 136, 6499.

24 GC-MS analysis of the reaction mixtures (Table 1, entries 78) revealed no formation of $\mathrm{Ar}-\mathrm{CF}_{2} \mathrm{CF}_{3}$ or $\mathrm{Ar}-\mathrm{CF}_{3}$, respectively. These results demonstrated quite different catalytic profiles in which $\mathrm{CF}_{3} \mathrm{CF}_{2}$ and $\mathrm{CF}_{3}$ did not serve as coupling ligands. Unlike the $\mathrm{CF}_{3} \mathrm{CH}_{2}$ counterpart, their reluctance to contribute as triggering coupling-ligand might be explained by the challenging $\operatorname{Ar}-R_{\mathrm{f}}\left(\mathrm{R}_{\mathrm{f}}=\right.$ perfluoroalkyl) reductive elimination. For related reference: G. G. Dubinina, W. W. Brennessel, J. L. Miller and D. A. Vicic, Organometallics, 2008, 27, 3933. 